\title{
IDENTIFIKASI KADAR TIMBAL (Pb) DALAM DARAH PADA PETUGAS OPERATOR SPBU 34-42115 KOTA SERANG
}

\section{IDENTIFICATION OF BLOOD LEAD LEVEL AMONG SPBU OPERATOR OFFICERS 34-42115 IN SERANG CITY}

\author{
Ghina Stamara, Diana Rinawati, Barlian Barlian \\ Poltekkes Kemenkes Banten \\ Korespondensi: dianarinawati14rina@gmail.com
}

\begin{abstract}
Blood is a means of transporting oxygen and spreading it throughout the liquid body. In the body, the blood has a main role as a means of transporting oxygen from cells to the lungs as well as for the defense of the human body against foreign substances. Lead in the blood is bound by erythrocytes, which are divided into two namely soft tissue and hard tissue. The SPBU officer as one of the groups that have a high risk of being directly exposed to lead. Lead exposure can come from vehicle emissions coming from or steam coming from gasoline when charging. This research is a descriptive study by examining the blood sample of SPBU 34-42115 Serang City Operator Officers to determine the concentration of heavy metals $(\mathrm{Pb})$. The instrument used in identifying $\mathrm{Pb}$ in the blood is ICP-OES (Inductively Coupled Plasma Optical Emission Spectrometry) with a wavelength of $283.3 \mathrm{~nm}$. The results of the study by identifying seven samples showed that the blood samples that were tested were not detected blood lead levels with a working period of $<4$ years. Under National and International Regulations regarding lead Based on the Circular of the Minister of Manpower of the Republic of Indonesia No. 01 / MEN / 1997 concerning the Threshold Value of Chemicals, the threshold value of lead exposure and its inorganic compound at work is $0.05 \mathrm{mg} / \mathrm{m3}$.
\end{abstract}

\section{Keywords: Blood, Metal Lead (Pb), ICP-OES}

\begin{abstract}
ABSTRAK
Darah adalah alat pengangkut oksigen dan menyebarkannya keseluruh tubuh yang bersifat cair. Didalam tubuh darah berperan utama sebagai alat transportasi oksigen dari sel ke paru-paru serta untuk pertahanan tubuh manusia terhadap zat asing. Timbal $(\mathrm{Pb})$ dalam darah diikat oleh eritrosit, yang dibagi menjadi dua yaitu ke jaringan lunak dan ke jaringan keras. Petugas SPBU sebagai salah satu kelompok yang mempunyai risiko tinggi untuk terpapar timbal secara langsung. Paparan timbal dapat berasal dari emisi kendaraan yang datang maupun uap yang berasal dari bensin saat pengisian. Penelitian ini merupakan penelitian deskriptif dengan melakukan pemeriksaan sampel darah petugas Petugas Operator SPBU 34-42115 Kota Serang guna mengetahui konsentrasi logam berat $(\mathrm{Pb})$. Alat yang pergunakan dalam mengidenetifikasi $\mathrm{Pb}$ dalam darah adalah ICP-OES (Inductively Coupled Plasma Optical Emission Spectrometry) dengan panjang gelombang 283,3 $\mathrm{nm}$. Hasil penelitian dengan mengidentifikasi tujuh sampel menunjukkan bahwa sampel darah yang telah diuji tidak terdeteksi kadar timbal dalam darah tersebut dengan masa kerja $<4$ tahun. Sesuai dengan Peraturan Nasional dan
\end{abstract}


Internasional mengenai timbal Berdasarkan Surat Edaran Menteri Tenaga Kerja Republik Indonesia No. 01/MEN/1997 mengenai nilai Ambang Batas Bahan-Bahan Kimia, nilai ambang batas paparan timbal dan persenyawaan anorganiknya di tempat kerja adalah sebesar $0,05 \mathrm{mg} / \mathrm{m}^{3}$.

\section{Kata kunci: Darah, Logam Timbal (Pb), ICP-OES}

\section{PENDAHULUAN}

Pertambahan jumlah kendaraan bermotor yang sangat pesat memberikan dampak negatif sebagai konsentrasi dari emisi yang dihasilkan. Kendaraan bermotor merupakan penyumbang utama dari seluruh emisi racun di udara. Penggunaan bahan bakar pada kendaraan bermotor dengan bilangan oktan yang tinggi dapat mengurangi ketukan pada mesin saat proses pembakaran bensin. Memang bila angka oktan tidak memadai, maka ketukan yang terjadi dapat merusak mesin atau mengurangi kinerja dan efisiensi mesin. Salah satu cara untuk menaikan bilangan oktandari sutau bahan bakar adalah dengan menambahkan $\mathrm{Pb}\left(\mathrm{C}_{2} \mathrm{H}_{2}\right)_{4}$, Tetra Ethyl Lead (TEL). Kedalam bahan bakar tersebut. Namun usaha menaikan bilangan oktan dengan menambahkan TEL akan mengakibatkan gas buang mengandung timbal yang beracun dan merusak lingkungan.

Pencemaran lingkungan dapat menyebabkan terjadinya bahaya toksik pada manusia (Dr. Mathilda B. Widianto, 1991). Limbah yang berpotensi merusak lingkungan adalah limbah yang termasuk kategori B3, yaitu Bahan Berbahaya dan Beracun. Di dalam limbah B3 ini terdapat logam-logam berat (Alsuhendra, 2013).

Di Indonesia saat ini kurang lebih $70 \%$ pencemaran udara disebabkan oleh emisi kendaraan bermotor yang mengeluarkan zat-zat berbahaya yang dapat menimbulkan dampak negative (Sugiarti, 2009). Menurut Environment Project Agency, sekitar 25\% logam berat tetap berada dalam mesin dan $75 \%$ lainnya akan mencemari udara sebagai asap knalpot (Gusnita, 2012).

Logam dilingkungan yang paling dikhawatirkan salah satunya adalah timbal, masyarakat dapat terpajan timbal setiap hari. (Joel G \& Lee E, 2015). Jika konsentrasinya pada lingkungan melebihi batas normal, maka lingkunga tersebut dianggap telah mengalami pencemaran logam berat. Dalam kehidupan sehari-hari, logam berat umumnya dapat berasal dari sumber alami berupa batu-batuan atau air, limbah industri, aktivitas penambangan, sarana transportasi, dan makanan (Alsuhendra, 2013). Kadar logam berat di 
lingkungan dapat berubah-ubah bergantung pada adanya perubahan dari kejadian alam, seperti hujan dan erosi, atau karena pencemaran dari berbagai aktivitas yang dilakukan manusia (Alsuhendra, 2013).

Paparan timbal yang masuk melalui udara sekitar 30-40\% akan diabsorbsi ke dalam darah. Di dalam darah timbal akan menghambat sintesis heme melalui pengikatan gugus thiol pada enzim Aminoluvucinic Acid Dehydrase. Timbal juga akan merusak enzim-enzim antioksidan seperti Superoxide dismutase (SOD), catalase (CAT), dan Gluthation Peroxidase (GPx) yang mengakibatkan pembentukan senyawa radikal bebas berupa Reactive Oxygen Species (ROS) tidak terkontrol. Ketidakseimbangan antara banyak radikal bebas dengan antioksidan menyebabkan stres oksidatif terjadi yang berkaitan dengan kerusakan membran sel, DNA, RNA dan kerusakan pada sel otak.

Kadar $\mathrm{Pb}$ dalam darah manusia adalah sekitar 10-25 $\mu \mathrm{g} / 100 \mathrm{ml}$ darah. Akan tetapi, ada sejumlah keci $\mathrm{Pb}$ yang masuk ke dalam tubuh (Alsuhendra, 2013). Rata-rata supan $\mathrm{Pb}$ per hari adalah sekitar 0,3 mg (Darmono, 1995). Timbal $(\mathrm{Pb})$ dalam darah diikat oleh eritrosit, yang dibagi menjadi dua yaitu ke jaringan lunak (sumsum tulang, sistem saraf, ginjal, dan hati) dan ke jaringan keras (tulang, kuku, rambut, dan gigi) (Palar, 1994).

Petugas Stasiun Pengisian Bahan Bakar Umum (SPBU) sebagai salah satu kelompok yang mempunyai risiko tinggi untuk terpapar timbal secara langsung. Paparan timbal dapat berasal dari emisi kendaraan yang datang maupun uap yang berasal dari bensin saat pengisian, sebagian besar menggunakan bensin premium yang mengandung Tetra Ethyl Lead (TEL) atau Tetra Methyl Lead (TEL). Kandungan timbal dalam tubuh dapat dideteksi melalui darah, rambut, urine, dan kuku. Beberapa penelitian melaporkan kadar timbal pada pekerja SPBU baik pria maupun wanita melebihi batas kadar aman dan menimbulkan berbagai gangguan kesehatan seperti hipertensi, rasa mual, kelelahan, susah bernapas, dan gusi berdarah.

\section{METODE}

Desain penelitian yang akan dilakukan adalah metode deskriptif dengan melakukan pemeriksaan terhadap Identifikasi Uji Kadar Timbal (Pb) Dalam Darah Pada Petugas Operator SPBU 3442115 Kota Serang. Populasi dari penelitian ini adalah darah dari petugas SPBU 34-42115 Kota Serang Banten yang 
berjumlah 21 orang. Sampel ditentukan secara purposive yaitu petugas SPBU yang bekerja dibawah 4 tahun, dengan kriteria sebagai berikut :

a. Petugas operator perempuan yang tidak merokok.

b. Petugas operator dengan masa kerja $<4$ tahun.

\section{HASIL DAN PEMBAHASAN}

Penelitian dilakukan di Laboratorium

Kesehatan Daerah Kota Jakarta pada tanggal 25 Maret 2019 dengan melakukan pemeriksaan Identifikasi Kadar Timbal $(\mathrm{Pb})$ Dalam Darah Pada Petugas Operator SPBU 34-42115 Kota Serang, dengan menggunakan alat Inductively Caoupled Plasma Optical Emission Spectrometry (ICP-OES) pada panjang gelombang 283,3 $\mathrm{nm}$. Hasil pemeriksaan dapat dilihat pada tabel 1 .

Tabel 1. Hasil pemeriksaan Identifikasi Kadar Timbal $(\mathrm{Pb})$ dalam Darah Pada Petugas Operator SPBU 34-42115 Kota Serang

\begin{tabular}{ccccc}
$\begin{array}{c}\text { Respon } \\
\text { den }\end{array}$ & $\begin{array}{c}\text { Umur } \\
\text { (th) }\end{array}$ & $\begin{array}{c}\text { Masa } \\
\text { Kerja } \\
\text { (th) }\end{array}$ & $\begin{array}{c}\text { Hasil Lab } \\
(\mu \mathrm{g} / 100 \mathrm{~mL})\end{array}$ & Ket \\
\hline $\mathrm{A}$ & 27 & 2,5 & 15,8 & $\mathrm{tt}$ \\
\hline $\mathrm{B}$ & 29 & 3,2 & 33,41 & $\mathrm{tt}$ \\
\hline $\mathrm{C}$ & 32 & 3,5 & 52,93 & $\mathrm{tt}$ \\
\hline $\mathrm{D}$ & 26 & 2,8 & 24,77 & $\mathrm{tt}$ \\
\hline $\mathrm{E}$ & 31 & 3,8 & 34,03 & $\mathrm{tt}$ \\
\hline $\mathrm{F}$ & 28 & 3 & 25,59 & $\mathrm{tt}$ \\
\hline $\mathrm{G}$ & 28 & 2,6 & 27,09 & $\mathrm{tt}$ \\
\hline
\end{tabular}

Berdasarkan tabel 1 dari sampel A, B, C, $\mathrm{D}, \mathrm{E}, \mathrm{F}$ dan $\mathrm{G}$ tidak terdeteksi adanya kandungan logam timbal dalam darah pada petugas operator SPBU 34-42115 Kota Serang.

Penelitian ini dilakukan untuk mengetahui kandungan timbal $(\mathrm{Pb})$ yang terdapat dalam darah pada petugas operator SPBU 34-42115 Kota Serang. Sampel yang digunakan dalam penelitian berupa petugas operator perempuan dengan masa kerja <4 tahun dan tidak merokok. Kriteria tersebut dipilih karena dalam jurnal dengan masa kerja hanya diatas $>4$ tahun, 5-6 tahun, dan $>7$ tahun terdeteksi adanya logam timbal dalam darah petugas operator tersebut, makanya sampel yang diuji memiliki kriteria masa kerja $<4$ tahun adakah timbal di dalam darah pada petugas operator tersebut.

Pada pemeriksaan kandungan timbal $(\mathrm{Pb})$ dalam darah pada petugas SPBU dilakukan pengukuran secara kuantitatif dengan menggunakan ICP- OES (Inductively Caoupled Plasma Optical Emission Spectrometry) dengan panjang gelomban 283,3 nm. Alat ini dipilih karena memiliki keunggulan yaitu suhu yang tinggi, kerapatan elektron tinggi (1.014$1.016 \mathrm{~cm}^{3}$ ), derajat ionisasi yang cukup besar untuk banyak unsur, kemampuan analisa multi unsur secara bersamaan, 
stabilitas yang tinggi, batas deteksi yang sangat baik untuk sebagian besar unsur (0,1-100 $\mathrm{ng} / \mathrm{mL})$, analisis dengan biaya yang lebih efektif dan waktu yang singkat (Octarianita, 2017).

Berdasarkan 7 sampel darah yang telah diuji didapatkan hasil pengukuran kadar timbal dengan kandungan logam yang diambil pada petugas operator SPBU 34-42115 Kota Serang, Kode sampel A dengan ciri fisik pasien berumur 27 tahun dan sudah bekerja selama 2,5 tahun, Kode sampel B dengan ciri fisik pasien berumur 29 tahun dan sudah bekerja selama 3,2 tahun, Kode $\mathrm{C}$ dengan ciri fisik pasien berumur 32 tahun dan sudah bekerja selama 3,5 tahun, Kode D dengan ciri fisik pasien berumur 26 tahun dan sudah bekerja selama 2,8 tahun, Kode E dengan ciri fisik pasien berumur 31 tahun dan sudah bekerja selama 3,8 tahun, Kode F dengan ciri fisik pasien berumur 28 tahun sudah bekerja selama 3 tahun dan Kode $\mathrm{G}$ dengan ciri fisik pasien berumur 28 tahun sudah bekerja selama 2,6 tahun.

Pada saat dilakukan pemeriksaan kandungan timbal $(\mathrm{Pb})$ pada sampel darah terlihat perubahan warna setelah ditambahkan larutan $\mathrm{HClO}_{4} \mathrm{P}$ Sehingga warna yang terlihat sama antara 7 sampel tersebut, dengan ditambahkannya batu di dalam sampel untuk menghindari terjadinya letupan selama pemanasan dan mempercepat terlarutnya sampel dalam darah yang tercampur larutan $\mathrm{HClO}_{4}$, kemudian di masukkan kedalam alat hot plate \pm 1 jam dan dinginkan pada suhu kamar, lalu pindahkan ke dalam labu ukur dan tambahkan aquadest sampai tanda batas dan masukkan ke dalam alat ICPOES.

Dari data tersebut dapat dikatakan bahwa dari 7 sampel tersebut tidak mengandung logam jenis timbal, sesuai dengan masa bekerja $<4$ tahun yang memiliki ambang batas kadar timbal dalam darah sekitar $30 \quad \mu \mathrm{g} / 100 \quad \mathrm{~mL}$ (Depkes, 2013).

Dikarenakan mayoritas sampel yang di uji petugas operator perempuan yang tidak merokok dengan lokasi yang tidak padat penduduk dan hanya satu lokasi pengambilan sampel darah sehingga hasil kemungkinan yang dapat mempengaruhi nilai normal tidak terdeteksi dan tidak sesuai dengan nilai ambang batas. Pekerja yang memiliki masa kerja >7 tahun memiliki kadar timbal $>25 \mu \mathrm{g} / \mathrm{dL}$ di dalam darah sedangkan untuk operator yang bekerja <4 tahun memiliki kadar timbal dalam darah sekitar 10-25 $\mu \mathrm{g} / \mathrm{dL}$, lamanya masa kerja ini membuat timbal terakumulasi dalam tubuh karena sifat timbal yang mudah terserap dalam 
jaringan tubuh. Timbal memiliki waktu paruh di dalam darah kurang lebih 25 hari, pada jaringan lunak 40 hari, sedangkan tulang 25 tahun. Timbal yang masuk ke dalam tubuh normalnya $0,3 \mathrm{mg} / 1.000 \mathrm{cc}$ perhari, jika intake timbal 2,5 $\mu \mathrm{g} /$ hari maka butuh waktu 3-4 tahun untuk mendapatkan efek toksik sedangkan infake timbal 3,5 $\mu \mathrm{g} /$ hari maka butuh waktu hanya beberapa bulan saja untuk terpapar timbal (Ayu, $d k k, 2016)$.

Penelitian ini untuk dibawah $<7$ tahun masa kerja pada petugas operator SPBU 34-42115 Kota Serang tidak terdeteksi adanya kadar timbal dalam darah dikarenakan nilai ambang batas yang digunakan menurut Departemen Kesehatan Republik Indonesia $30 \mu \mathrm{g} / 100$ mL (Depkes, 2003).

Faktor umur sangat erat kaitannya dengan kadar timbal dalam darah pada kelompok petugas SPBU. Umur seseorang akan menentukan kadar timbal yang terdapat darahnya. Semakin tua umur seseorang maka akan tinggi pula konsentrasi $\mathrm{Pb}$ yang terakumulasi pada jaringan tubuhnya dikarenakan apabila seseorang semakin tua, maka tubuhnya semakin tidak bisa menetralisir racun masuk ke dalam tubuh (Bada, 2013).

Keberadaan logam berat yang terhirup oleh petugas operator SPBU setiap harinya ada yang menggunakan APD dan ada yang tidak menggunakan Alat Perlindungan Diri (APD) dapat membahayakan kesehatan tubuhnya. Setiap asap knalpot yang terhirup dapat menyebabkan kerusakan pada sistem pernafasan, sebaiknya para petugas menggunakan APD yang telah disediakan oleh perusahaan agar tidak terhirupnya logam timbal yang masuk kedalam tubuh kita. Karena timbal yang terhirup dan masuk pada sistim pernapasan akan ikut beredar ke seluruh jaringan dan organ tubuh.

Deteksi akan adanya timbal dapat dilihat di darah karena lebih dari 90\% logam timbal yang terserap oleh darah berikatan dengan sel darah merah dan mengakibatkan gangguan pada proses sintesis hemoglobin. Gejala keracunan timbal yang dikeluhkan umumnya meliputi kram perut yang parah, sakit kepala, kehilangan nafsu makan dan anemia. Kadar timbal dalam darah merupakan indikator pemajanan yang sering dipakai dengan pajanan eksternal. Kadar timbal dalam darah merupakan petunjuk langsung jumlah timbal yang masuk ke dalam tubuh.

Logam $\mathrm{Pb}$ diekskresikan dengan sangat lambat. Waktu paruhnya adalah sekitar 40 tahun. Sasaran utama dari 
keracunan $\mathrm{Pb}$ adalah tubulus proksimal ginjal (Alsuhendra, 2013). Pada kasus keracunan kronis gejala dan gangguan kesehatan pada awalnya tidak terlihat. Akan tetapi lama kelamaan semakin meningkat dan menyebabkan depresi, sakit kepala, sulit berkonsentrasi, gangguan daya ingat dan sulit tidur (Alsuhendra, 2013). efek ini meliputi Sebagian besar $\mathrm{Pb}$ yang terhirup pada saat bernafas akan masuk ke dalam pembuluh darah paruparu. Penyerapan $\mathrm{Pb}$ dipengaruhi oleh ukuran partikel dari senyawa $\mathrm{Pb}$ yang ada dan volume udara yang mampu dihirup pada saat peristiwa bernafas berlangsung. Logam $\mathrm{Pb}$ yang masuk ke paru- paru melalui pernafasan akan terserap dan berikatan dengan darah paru-paru, SSP, dan tulang kemudian diedarkan ke seluruh jaringan dan organ tubuh seperti kulit, ginjal dan usus. Gejala keracunan akut seperti mual, muntah, sakit perut hebat, kelainan fungsi otak, anemia berat, kerusakan ginjal bahkan menyebabkan kematian (Alsuhendra, 2013). Partikel dengan diameter aerodinamik diatas $5 \mu \mathrm{m}$ terutama terdeposit di dalam saluran pernafasan bagian atas, yang dibersihkan dengan mekanisme secara mukosiliar dan penelanan. Sebagian dari timbal tersebut akan terabsorpsi kedalam saluran pencernaan.
Diperkirakan, absorpsi timbal yang stabil dalam saluran pencernaan orang dewasa rata-rata sebesar $10 \%$. Orang dewasa mengabsorbsi $\mathrm{Pb}$ sebesar 5-15\% dari keseluruhan $\mathrm{Pb}$ yang dicerna, sedangkan anak-anak mengabsorbsi $\mathrm{Pb}$ lebih besar, yaitu 41,5\%. Di dalam tubuh manusia, $\mathrm{Pb}$ bisa menghambat aktivitas enzim yang terlibat dalam pembentukan hemoglobin $(\mathrm{Hb})$ dan sebagian kecil $\mathrm{Pb}$ diekresikan lewat urin atau feses. Ekresi $\mathrm{Pb}$ melalui sistem urinaria adalah sebesar $76 \%$, gastrointestinal $16 \%$ dan rambut, kuku, serta keringat sebesar $8 \%$ (Widodo.et al., 2008).

\section{SIMPULAN}

Penelitian ini menyimpulkan bahwa kandungan timbal $(\mathrm{Pb})$ pada sampel darah tidak terdeteksi dan tidak melebihi ambang batas maksimal nilai normal menurut depkes, Sampel yang diuji sesuai dengan masa kerja operator yang bekerja $<4$ tahun, yang memiliki kadar ambang batas timbal dalam darah sekitar $30 \mu \mathrm{g} / 100 \mathrm{~mL}$ dan Pekerja seorang perempuan yang tidak merokok.

\section{DAFTAR PUSTAKA}

Almunjilat, dkk. 2016. Analisis Risiko
Kesehatan Akibat Pajanan Timbal (Pb)
Melalui Jalan Inhalasi Pada Operator Di
Stasiun Pengisian Bahan Bakar Umum 
(SPBU). Kendari. Fakultas Kesehatan Masyarakat Universitas Halu Oleo.

Alsuhendra,dkk. 2013. Bahan Toksik dan Makanan. Bandung. PT. Remaja

Ayu, Friska And Afridah, Wiwik And Nourma, Muslikha (2016) Hubungan Karakteristik Pekerjaan Dengan Kadar Timbal Dalam Darah (Pbb) Pada Operator Spbu Di Kecamatan Tamalanrea Kota Makassar Tahun 2016. Buku Program Dan Abstrak Konas Iakmi Xiii. Issn 978-602-60432-0-7

Bada,dkk. 2013. Faktor Yang Berhubungan Dengan Kadar Timbal (Pb) Dalam Darah Sopir Koperasi Angkutan Kota Mahasiswa dan Umum (KAKMU) Trayek 05 Kota Makassar. Makassar. Universitas Hasanuddin.

Darmono. 2008. Farmasi Forensik dan Toksikologi. Jakarta. Universitas Indonesia (UI-Press).

Darmono. 1995. Logam Dalam Sistem Biologi Makhluk Hidup. Jakarta. UI Press. Darmono. 2009. Penerapan teknologi Bahan Bangunan Berbahan Pasir bagi

Korban Gempa di kulonprogo Serta Analisa Mutu dan Ekonominya. Diakses 10 November 2015.

Depkes. 2013. Pedoman Pemeriksaan Toksikologi Logam Berat Dengan Metode SSA. Jakarta. Direktorat Jenderal Pelayanan Medik.

Fibrianti, dkk. 2015. Karakteristik Kadar Timbal (Pb) Dalam Darah Jurnal Kesehatan Lingkungan Vol. 8 No. 1. Surabaya. Universitas Airlangga.

Gusnita, Dessy. 2012. Pencemaran Logam berat timbal $(\mathrm{Pb})$ diudara dan upaya penghapusan bensin bertimbal. Berita Dirgantara. Vol. 13(3): 95-101. September 2012.

Hardman, Joel, G, dkk. 2012. Goodman \& Gilman Edisi 10. Jakarta. EGC. Hou, X.
\& B. T. Jones. 2000. Inductively Coupled Plasma/Optical Emission

Spectrometry. R. A. Meyers (Ed) Encyclopedia of Analytical Chemistry:9468-9485.

http://lib.unnes.ac.id/18723/1/4311409063.pdf https://kliksma.com/2015/04/pengertianunsur-timah-hitam-dan-efeknya.html

https://media.neliti.com/media/publications/10 6562-ID-kadar-timbal-darah-dankeluhan-kesehatan.pdf

Lu, Frank C. 1995. Toksikologi Dasar Edisi 2. Jakarta. Universitas Indonesia (UI).

Octarianita, Eva. 2017. Analis Kandungan Logam Berat Pada Kerang di Pasar Gudang Lelang dan PPI dengan metode ICP-OES. Skripsi. Program Sarjana FMIPA. Universitas Lampung.

Palar, Heryando. 2012. Pencemaran dan Toksikologi Logam Berat Cet. 4. Jakarta: Rineka Cipta.

Perkin-Elmer Corporation. 2008. World Leader in $A A$, ICP-OES, and ICP-MS. USA. Perkin-Elmer

Widianto, dkk. 1991. Dinamika Obat oleh Ernst Mutschler edisi ke-5. Bandung. ITB

Wiratama, dkk. 2018. Studi Bioakumulasi Ion Logam Pb Dalam Rambut dan Darah Operator Stasiun Pengisian Bahan Bakar Umum. Samarinda. Universitas Mulawarman.

Yuni, Natalia, Erlina. 2015. Kelainan Darah. Yogyakarta. Nuha Medika. 